\title{
Critical discursive psychology: In and against Psychology
}

[ B O O K REVIEW]

Parker, Ian (2015) Critical discursive psychology. 2nd edition. Houndmills: Palgrave Macmillan (2002). ISBN 978-1137-48559-5 hbk. Pages xiii +303

Ian Parker's book Critical discursive psychology (second edition 2015), comprises texts related to the rise of new critical traditions in psychology along with current debates within the discipline. At the very beginning of the introduction, lan Parker presents the scope or territory of the content and debatable issues. The book has a polemic aspect in that Parker has invited critical responses to his work, which are included in this volume, to which Parker then also responds. This style is consistent with Parker's interest to show critical discursive psychology in action, and thus allows readers to understand the ongoing contemporary debates on various topics.

Critical discursive psychology consists of three parts. Part I discusses the enlightenment, realism and power; Part II intensively focuses on discourse, context of discourse, discourse analysis, and practical problems a researcher might face while doing discourse analysis; and Part III is about critical discursive research, subjectivity and practice in psychology. This book deals with two aspects of critical activities. Firstly, it treats traditional psychology with doubt since it treats mind and behaviour as factual. Secondly, it rejects the location of mental phenomena to be inside people's head as traditional psychology does, and rather it treats it to be located in language and this operating between people. This book discusses two approaches to discourse which are the Foucauldian approach and interpretative repertoires,
Umme Habiba Jasmine

PhD candidate in

Psychology

University of the

Witwatersrand, \&

Lecturer Department of

Psychology

University of Rajshahi

Dhaka, Bangladesh

uhjasm@gmail.com 
which have been developed from different theoretical traditions, though there are some overlaps sometimes.

Ian Parker is one of the critical psychologists who focuses on questioning the founding assumptions of psychology and criticizes current psychology as an "American" discipline. This book has been written in and against psychology. One important philosophy of Parker is that working against a theoretical position should be working in and against it dialectically. According to Parker, what we study in psychology is the discourse of human actions and experience as part of "powerful discursive practices of Western culture" (p130) that designates what is normal and what is abnormal (see Parker et al, 1995). Critical psychologists have attended to the role psychology has played in Western colonialism and racism (Teo, 2005). Parker alerted against the generalization of psychological findings from white North American culture. He even identified the difference between the white cultures of the US and the UK. According to Parker it is necessary to know about the debates among different epistemological positions of psychology to sharpen our thinking to know about the "problematic" character of psychology. To support his arguments he has used the works of Michel Foucault, Jacques Derrida, Jacques Lacan, and Ken Gergen in different discussions of topics.

In this book, Parker has identified three rules of the discipline of psychology to break, which are: "Don't talk about yourself", "Don't work with theory", and "We should not address psychoanalysis". He clearly declared that he never believed in psychology, neither in its little findings nor the grand theories. He declared his political position to be revolutionary Marxism and criticized the political position of psychology as a discipline to be in the service of capitalism. Parker has warned against separating mind from body, hence psychology does not make sense if it is separated and not studied in its whole context (both body, mind, and culture). Parker has also criticized male stereotypical notions of psychology and has put the urgency of developing intellectual resources in human science contexts such as cultural studies, women's studies and literary theory.

This is an era of critical psychology when founding assumptions of psychology as a discipline are being questioned. The rise of the feminist approach and discursive psychology argue about the influence of power to social structuring and the role of language in the "creation of psychological facts and subjective experiences" ( $p 1)$. Critical psychology alerts us to the danger of taking cultural preoccupations for granted and assume them to be our common sense. That is why critical psychology plays an important role by studying how psychology is culturally and historically constructed and how other culturally founded psychologies may contest the mainstream models.

Parker also draws our attention to psychoanalysis while discussing theoretical discourse, 
subjectivity and critical psychology in chapter 1 . He has pointed out the theoretical works needed to draw out the critical potential of psychoanalysis and has debated about the contributions and reservations of psychoanalytic ideas in psychosocial research. Parker has underscored that psychoanalysis is a repressed other of psychology.

Part I of this book comprises of three polemics which are the postmodern argument about the nature of the world, Wittgensteinian notions of language and language games, and relativist refusals of the kinds of truth that psychologists assume. A common thread running throughout Parker's text is the importance of assessing theoretical positions dialectically and he thus demands a dialectical assessment of theoretical positions.

Parker characterized the four aspects of postmodernism (relativism, amoralism, collectivism, and autonomy) as "qualitatively more irrational and unpleasant version" ( $p$ 52) of each of the four aspects of modern psychology (regularity, essentialism, reductionism, and individualism). He has commented several times that postmodernism, which has given the cultural background in theoretical research, has outlived its usefulness. Parker argues instead for a new radical agenda in research to avoid the dangers of postmodernism in psychology. Postmodernism has threatened the radical political agenda in psychology as a discipline. Parker has employed a dialectical critique against postmodernism (see his debates with Newman \& Holzman in this volume). However, Parker is also somewhat of a postmodernist, but he has criticized it from a certain concept of dialectics, which is different from what other postmodernists do. Parker's critique of postmodernism has been criticized by Newman and Holzman (chapter 2a):

"But Parker is in the business of critiquing and predicting what is already known, and he failed to note that we happen to be a group of people who self-consciously tried to create an emancipatory environment that nurtures the play of development instead of replicating an authoritarian environment that insists on the serious business of knowing." ( $p$ 57)

Newman and Holzman agree with Parker's call that postmodernism has "outlived its usefulness" saying that it might have lost its usefulness, but has not lost its importance.

In this book Parker discusses his position on relativism and realism (chapter 3). Though relativism has disentangled the truth claims and oppressive practices of psychology as a discipline, it is not enough to understand and combat the discipline as part of the "psy-complex". So, Parker has argued for the need of dialectical work on a balanced review of the flaws and contributions of relativism. Hence, he talked about rhetorical balancing strategies. Parker has criticized relativism saying that it has played a profound 
ideological role and also that it has torn morality from epistemology. He looks at critical realism as capable of repairing this flaw of relativism.

Potter, Edwards and Ashmore (chapter 3a) have criticized Parker's critique of relativism claiming a range of basic errors and contradictions in Parker's argument and concept of relativism. They conclude their argument claiming that the intention behind Parker taking a critical realist position acts as a three-layer safety curtain to save the "Parker complex" from burning, and to avoid empirical work which Parker is critical of, and also to avoid scholarly interdisciplinary engagement. They draw on a concept called the "Parker complex" to indicate the problems arising from Parker's dense network of theories and arguments with politics, philosophy and psychology. Parker responded to Potter et al's criticism (chapter $3 \mathrm{~b}$ ) clarifying each of their theoretical positions saying that Potter et al's position on relativism leans to uncritical realism whereas his own position on critical realism is more critically relativist.

In part II of this book, Parker has proposed an adequate definition of discourse, and seven criteria and beyond to identify discourses. There is an internal argument in psychology which is that discourse lies in the centre of human action. He also proposes three additional criteria to relate discourse analysis and political issues. It signifies discursive analysis to be a "resource" for radical mental health practice. While talking about discourse analysis Parker emphasized the form of analysis to be important, not only the content. This book critically reflects the promises of "critical discursive psychology" in the past, what it is now and the "to dos" to keep it critical. Discursive works were regarded as non-psychological even anti-psychological at the beginning but now the application of discourse analysis is established in different areas of psychology ranging from children's accounts to mental health and even to policy documents.

Abrams and Hogg (chapter $6 \mathrm{~b}$ ) have questioned the workability of distinctively defining discourse as separate from other aspects of human life. They also expressed their concern on Parker's portraying discourse as "abstracted, reified and unconnected with individual or social psychological processes" ( $p$ 177). Rather they preferred a discourse analysis that focuses on social processes. Their concern about methodological rigour has been raised from a quantitative point of view where they attuned with Potter and Wetherell's position (1987), and emphasized the representativeness of evidence over discourse analysts which requires the methodology to be reliable and valid.

In this book, Parker states the five axes of debate that structure how discourse analysis is conceptualized in psychology at present and discusses three essential discourses in psychology which are empirical, theoretical and political discourse. Five specific issues are that directed some varieties of discursive psychology to be more psychological than

PINS [Psychology in Society] 53 • 2017|104 
critical, which are interpersonal interaction, formal sequences, everyday conversation, empirical claims, and disciplinary fidelity. Cultural parameters determine traditional and alternative psychology, and so it is the role of "critical" psychology to consider the context of the discussion (e.g. Sloan, 2000). According to Parker (1999: 13), it is the role of critical psychology to explore how professional work and academic psychology is formed by everyday "ordinary psychology" and the way everyday activities cause resistance to modern disciplinary practices. To Parker (1999), critical psychology should systematically examine the politics or processes of some varieties of psychological concepts to be privileged over others, and the process of the dominant accounts of psychology that serve those who are in power.

\section{References}

Parker, I (1999) Critical psychology: Critical links. Annual Review of Critical

Psychology, 1, 3-18.

Parker, I, Georgaca, E, Harper, D, McLaughlin, T, \& Stowell-Smith, M (1995)

Deconstructing psychopathology. London: Sage.

Potter, J \& Wetherell, M (1987) Discourse and social psychology: Beyond attitudes and behaviour. London: Sage.

Sloan, T (ed) (2000) Critical Psychology: Voices for change. London: Macmillan.

Teo, $\mathrm{T}$ (2005) The critique of psychology: From Kant to postcolonial theory. New York: Springer. 